\title{
ACUTE EFFECT OF DIFFERENT TYPES OF EXERCISE ON NATRIURETIC PEPTIDES OF WISTAR RATS
}

\section{EFEITO AGUDO DE DIFERENTES TIPOS DE EXERCICIO SOBRE PEPTIDEOS NATRIURETICOS DERATOS WISTAR}

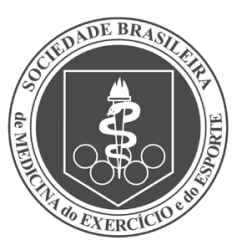

Original Article Artigo Original Artículo Original
Eduardo Vitor Pianca (Physiotherapist)

Walter Krause Neto ${ }^{2}$ (Physical Education Professional) Alexandre Sabbag da Silva ${ }^{3}$ (Physiotherapist)

Eliane Florencio Gama² (Physiotherapist)

Romeu Rodrigues de Souza² (Physician)

1. Faculdade Anhanguera, Department of Physiotherapy, São Paulo, SP, Brazil.

2. Universidade São Judas Tadeu, Department of Physical Education, Laboratory of Morphoquantitative Studies and Immunohistochemistry, São Paulo, SP, Brazil.

3. Universidade Mackenzie, Department of Physiotherapy, São Paulo, SP, Brazil.

Correspondence:

Walter Krause Neto Universidade São Judas Tadeu, Unidade Mooca.

Rua Taquari, 546, Mooca, São Paulo, SP, Brazil. 03166-000. wild_krause@hotmail.com

\begin{abstract}
Introduction: The study of the effects of different types of physical exercise on cardiovascular physiology is increasing in the literature. The many mechanisms of hemodynamic control include the atrial release of natriuretic peptides. Although extensive evidence demonstrates their acute effects and the increase in their plasma concentration, it is not known whether both atria respond in a similar way to both types of natriuretic peptide in response to different types of exercise. Objective: To compare the acute responses of different exercise types in the atrial (ANP) and brain (BNP) natriuretic peptides of both atrial cardiomyocytes of Wistar rats. Methods: Animals were divided into control (CG), aerobic (AG), resistance (RG) and combined (ARG). The RG performed six climbs, with a load equivalent to $60 \%$ of body weight. The AG ran on a treadmill at a speed of $12 \mathrm{~m} / \mathrm{min}$ for 60 minutes. The ARG exercise consisted of three consecutive ladder climbs, followed by 30 minutes of running. Results: First, the right atrium released more ANP and BNP during all types of exercise; second, the resistance exercise released the most ANP and BNP in both atria; third, in the right atrium, aerobic and combined workouts released more small and medium ANP granules while resistance exercise released larger BNP granules; and fourth, in the left atrium, aerobic exercise released more ANP granules while resistance and combined exercise released larger ANP and BNP granules. Conclusion: All types of exercise induce partial release of natriuretic peptide granules, with greater response to resistance exercise. Furthermore, a particular and different response could be seen in both types of atria in the release of ANP and BNP. Level of evidence Il; Therapeutic studies - Investigation of treatment results.
\end{abstract}

Keywords: Heart; Cardiovascular system; Exercise; Physical exercise; Anatomy.

\section{RESUMO}

Introdução: O estudo dos efeitos de diferentes tipos de exercício fisico na fisiologia cardiovascular está aumentando na literatura. Os muitos mecanismos de controle hemodinâmico incluem a liberação atrial de peptídeos natriuréticos. Embora amplas evidências demonstrem seus efeitos agudos e o aumento na sua concentração plasmática, não se sabe se ambos os átrios respondem de maneira semelhante aos dois tipos de peptídeos natriuréticos em resposta a diferentes tipos de exercício. Objetivo: Comparar as respostas agudas de diferentes tipos de exercícios nos peptídeos natriuréticos atrial (ANP) e cerebral (BNP) de ambos os cardiomiócitos atriais dos ratos Wistar. Métodos: Os animais foram divididos em: controle (GC), aeróbico (GA), resistência (GR) e combinado (GAR). O GR realizou seis escaladas com uma carga equivalente a $60 \%$ do peso corporal. O GA correu em esteira a uma velocidade de $12 \mathrm{~m} /$ min durante 60 minutos. O exercício do GAR consistiu em subir a escada três vezes consecutivas, seguido de 30 minutos de corrida. Resultados: Primeiro, o átrio direito liberou mais ANP e BNP durante todos os tipos de exercícios; Segundo, o exercício de resistência liberou mais ANP e BNP em ambos os átrios; Terceiro, no átrio direito, os exercícios aeróbicos e combinados liberaram mais grânulos de ANP pequenos e médios, enquanto o exercício de resistência liberou grânulos maiores de BNP; e, quarto, no átrio esquerdo, o exercício aeróbico liberou mais grânulos de ANP, enquanto os exercícios de resistência e combinados liberaram grânulos maiores de ANP e BNP. Conclusão: Todos os tipos de exercício induzem a uma liberação parcial dos grânulos de peptídeos natriuréticos com maior resposta ao exercício de resistência. Além disso, foi possivel verificar uma resposta particular e diferente em ambos os tipos de átrios na liberação de ANP e BNP. Nível de evidência ll - Estudos terapêuticos - Investigação dos resultados do tratamento.

Descritores: Coração; Sistema cardiovascular; Exercício; Exercício físico; Anatomia.

\section{RESUMEN}

Introducción: El estudio de los efectos de diferentes tipos de ejercicio físico en la fisiología cardiovascular está aumentando en la literatura. Los muchos mecanismos de control hemodinámico incluyen la liberación atrial de péptidos natriuréticos. Aunque amplias evidencias demuestren sus efectos agudos y el aumento en su concentración plasmática, no se sabe si ambos atrios responden de manera semejante a los dos tipos de péptidos natriuréticos en respuesta a diferentes tipos de ejercicio. Objetivo: Comparar las respuestas agudas de diferentes tipos de ejercicios en los péptidos natriuréticos atrial (ANP) y cerebral (BNP) de ambos cardiomiocitos atriales de ratas Wistar. Métodos: Los animales fueron divididos en: control (GC), aeróbico (GA), resistencia (GR) y combinado (GAR). El GR realizó seis escaladas con una carga equivalente a $60 \%$ del peso corporal. El GA corrió en cinta a una velocidad de $12 \mathrm{~m} / \mathrm{min}$ durante 60 minutos. El ejercicio del GAR consistió en subir la escalera tres veces consecutivas, seguido de 30 minutos 
de carrera. Resultados: Primero, el atrio derecho liberó más ANP y BNP durante todos los tipos de ejercicio; segundo, el ejercicio de resistencia liberó más ANP y BNP en ambos atrios; tercero, en el atrio derecho, los ejercicios aeróbicos y combinados liberaron más gránulos de ANP pequeños y medianos, mientras que el ejercicio de resistencia liberó granos mayores de BNP; y cuarto, en el atrio izquierdo, el ejercicio aeróbico liberó más gránulos de ANP, mientras que los ejercicios de resistencia y combinado liberaron gránulos mayores de ANP y BNP. Conclusión: Todos los tipos de ejercicio inducen una liberación parcial de los gránulos de péptidos natriuréticos con mayor respuesta al ejercicio de resistencia. Además, fue posible verificar una respuesta particular y diferente en ambos tipos de atrios en la liberación de ANP y BNP. Nivel de evidencia II - Estudios terapéuticos - Investigación de los resultados del tratamiento.

\section{Descriptores: Corazón; Sistema cardiovascular; Ejercicio; Ejercicio físico; Anatomía.}

\section{INTRODUCTION}

The maintenance of blood pressure (BP) and the knowlegde of the mechanisms of its control are fundamental for cardiovascular health. ${ }^{1-3}$ As far we know, several physiological systems work to control cardiovascular homeostases, such as the neuroendocrine, kidneys and adrenal glands. ${ }^{4-7}$

From all mechanisms already known, it is important to highlight specific factors, such as the atrial (ANP) and brain (BNP) natriuretic peptides. ${ }^{8,9}$ Natriuretic peptides (NP) play an important homeostatic role in cardiocirculatory hemodynamics through their action on the renal function. Recently, it has been shown that these peptides have other functions besides to that related to the BP control mechanism, such as promoting increased cardiac propulsion force and consequently cardiac output. ${ }^{10}$

These peptides are stored mainly in the atria and to a lesser extent in the ventricles and kidneys. ${ }^{11}$ Most of the natriuretic peptide granules are located near the cardiomyocyte nucleus, close to the mitochondria and the Golgi apparatus. ${ }^{12}$ On the other hand, BNP granules are smaller, have no membrane limiting and are present in atrial and ventricular cardiomyocytes..$^{13,14}$

Atrial dilation, due to pressure overload, triggers the release of the peptides into the bloodstream, promoting the acute effects of NPs, including increased glomerular filtration rate and renal excretion of $\mathrm{Na}^{+}$ and water, through inhibition of NaK ATPase pump and epithelial sodium channels (ENaC), as well as suppression of renin and aldosterone secretion. It's known that some stress situations might induce the release of NPs to counterbalance the increase of BP.

Stress condition is known as any situation that causes a breakdown of homeostasis and triggers spontaneous physiological responses. Among all, physical exercise, whether aerobic, resisted or combined, is known as a health-trigger stress type. ${ }^{15-18}$ Studies have shown that during these different types of physical exercise, the ANP and BNP levels increase significantly in the plasma. ${ }^{9,19}$ However, it is not known how much of these NPs are released during the practice of a physical training session.

Thus, the aim of the present study was to compare the acute responses of aerobic, resisted and combined exercise in ANP and BNP granules of the right and left atrial cardiomyocytes of Wistar rats.

\section{MATERIALS AND METHODS}

The present study was submitted and approved by the Bioethics Commission of the University of São Paulo (protocol 2476/2011).

Twenty-eight adult male Wistar rats at 3 months of age, weighing approximately $230 \mathrm{~g}$, were kept in collective boxes (four each), environment with a temperature of $23^{\circ} \mathrm{C}$ and inverted light-dark cycle, controlled every 12 hours. The rats had free access to a diet containing $52 \%$ carbohydrates, $21 \%$ proteins, and $4 \%$ lipids (NUVILAB CR1, NUVTAL Nutrientes LTDA, Curitiba, PR) and received water ad libitum.

The animals were equally randomly distributed into four groups: control (GC), aerobic exercise (GA), resistance exercise (GR) and combined exercise (GAR).

\section{Training protocols}

The rats of the GA, GR and GAR groups underwent a five-day familiarization period in their respective training equipment.

The equipment was constructed as described by Hornberger and Farrar ${ }^{20}$ measuring $110 \mathrm{~cm}$ in height, with steps of iron and slope of 80 degrees. The exercise was performed during the morning in a single session. Each rat performed six consecutive climbs, with a load equivalent to $60 \%$ of body weight, resting 120 seconds between each climb.

The aerobic exercise was performed on a treadmill at a speed of $12 \mathrm{~m} / \mathrm{min}$ for 60 minutes.

The combined exercise consisted of three consecutive climbs (120 secs pauses) with a load equivalent to $60 \%$ of body weight, followed by 30 minutes of treadmill running at a speed of $12 \mathrm{~m} / \mathrm{min}$.

\section{Preparation of material}

After euthanasia, the right and left atria were removed, fragmented and placed in 2.5\% glutaraldehyde-fixing solution in phosphate buffer solution $(0.2 \mathrm{M}, \mathrm{pH} 7.3)$ for three hours. Thereafter, they were washed three times with the same buffer solution for 5 minutes each time and subsequently placed in a solution of $1 \%$ osmium tetroxide in phosphate buffer for 2 hours. The fragments remained overnight in 0.5\% uranyl acetate and, after being washed with the buffer, were dehydrated in increasing series of alcohols and propylene oxide for 8 hours under rotation. The fragments were then included in pure resin for 5 hours and finally left in the same resin at $60^{\circ} \mathrm{C}$ for 5 days. The ultra-thin sections were obtained with an ultramicrotome diamond knife (Sorvall MT-2) and, after being tested with uranyl acetate and lead citrate, they were analyzed by the transmission electron microscope (Jeol, ICB, USP).

\section{Morphometric analysis}

In electron photomicrographs with $\times 15,000$ increase, the number of granules of both ANP and BNP, present in a previously delimited field, without including the nucleus, in ten electronic micrographs per animal was counted. The field was delimited by 4 lines constituting a parallelogram with sides of $5.0 \mu \mathrm{m}$ by $3.0 \mu \mathrm{m}$, totaling an area of 15.0 $\mu \mathrm{m}$ (Figure 1). In these same micrographs, the largest diameter of each granule was measured. (Figure 2)

Counts and measurements were obtained using the computerized image analysis program (Axio Vision, Zeiss). A total of 300 fields (micrographs) were analyzed in all four groups of animals. The values obtained were tabulated and later used to obtain the means and standard deviations.

Next, the percentages of small, medium and large granules present in each of the atria were calculated. The calculation to obtain the percentage of the ANP and BNP granules according to their size was made as explained below. The values obtained from the measurements of the granule diameters were placed in an Excel spreadsheet and arranged in a column from the smallest to the largest value. Then, the lowest value of the largest was subtracted and the result was divided into 3 groups, 


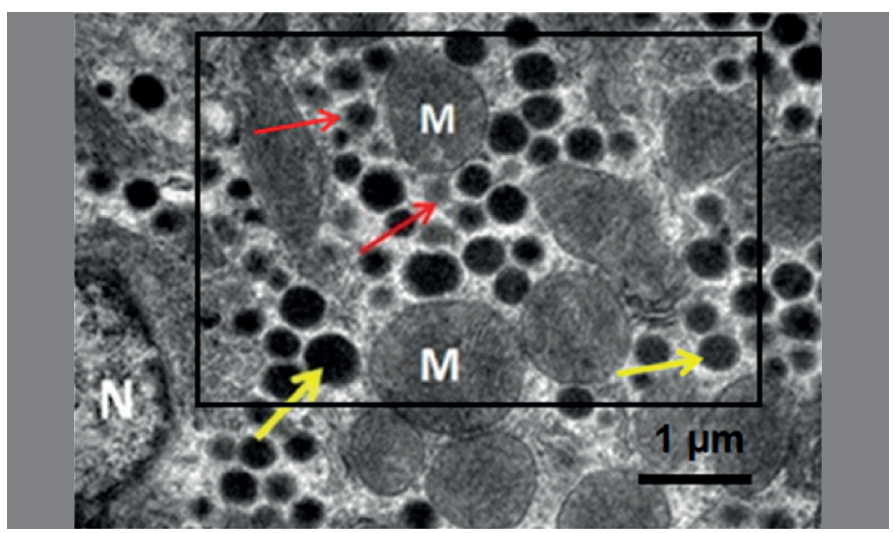

Figure 1. Electron micrograph of right atrium cardiomyocyte of Wistar rats, used for counting and measuring the diameter of ANP (yellow arrows) and BNP (red arrows) granules. N-Nucleus, M-mitochondria.

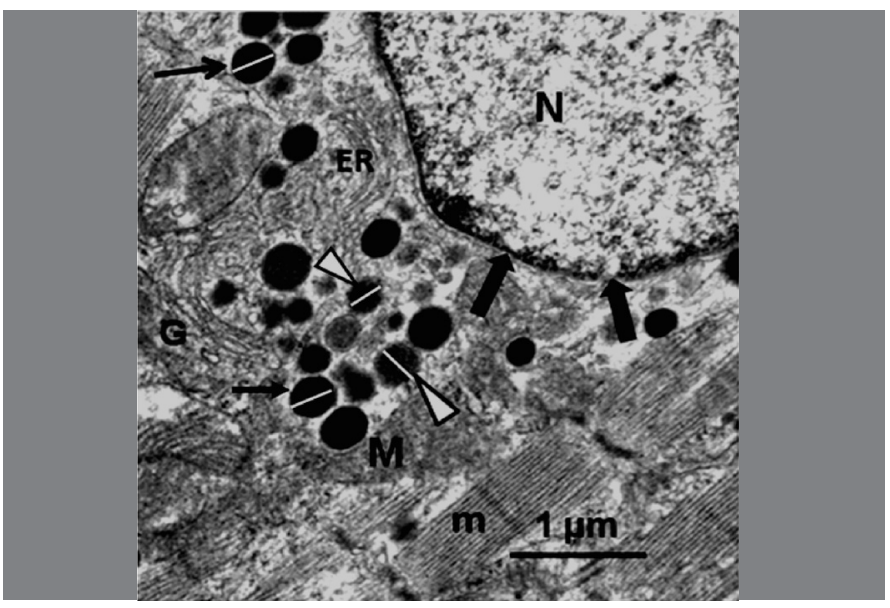

Figure 2. Electron micrograph of the right atrium Wistar rat cardiomyocyte, showing ANP granules and their diameter (arrows), BNP and its diameter (arrowheads), mitochondria (M), endoplasmic reticulum (ER), the Golgi apparatus (G), myofibrils ( $m$ ) in the cytoplasm of the cardiomyocyte and two pores of the nuclear membrane (thick arrows). N-nucleus.

according to the diameter value. Thus, for the control group, for the ANP, the lowest value was $16 \mu \mathrm{m}$ and the highest was $114 \mu \mathrm{m}$. Subtracting 16 of 114, we obtained the value of 98 . Dividing 98 by 3 (classes of small, medium and large) we obtained the aproximate value of 32. Thus, the granules of size up to 32 were classified in small; the granules from 33 to 65 were classified as medium and those above 65 were classified as large. The percentages of these three types of granules were then calculated for size. The total granules in this example (419) correspond to $100 \%$ and the number of small (ie up to 32 ) granules was 41 . Thus, the percentage of small granules corresponded to $10 \%$. This procedure was used for the other similar calculations.

The numerical density of pores per $10 \mu \mathrm{m}$ of nuclear membrane in the cardiomyocyte nuclei was determined in 10 electron micrographs per animal/group. (Figure 2)

\section{Statistical analysis}

All quantitative results were expressed as a mean and standard deviation (SD). For comparisons between the groups, the one-way ANOVA analysis (Tukey post-hoc ANOVA) with a significance level set at $p \leq 0.05$ was applied.

\section{RESULTS}

\section{Right atrium}

The ultrastructural analysis of the right atrium suggested a decrease in the number of granules of ANP and BNP in all groups in relation to the GC group. (Figure 3)
Yet, electron micrographs of the cardiomyocytes of the right atrium showed ANP and BNP granules of different sizes from all groups. (Figure 4)

The results demonstrated that the number of ANP granules per area in the GC group was larger than other groups ( $p<0.05)$. GA and GAR presented statistically fewer granules than GC. GR had significantly fewer granules than all groups $(p<0.05)$. The diameter of ANP granules was not statistically different between groups. (Figure 5)

Also, the results showed a significant decrease in the density of ANP granules in the GA, GR and GAR compared to the GC group ( $p<0.05$ ).

The results showed that the number of BNP granules per area in the GR was statiscally fewer than GC group ( $p<0.05)$. The diameter of the BNP granules in the GR was significantly small than all other groups $(p<0.05)$. (Figure 6)

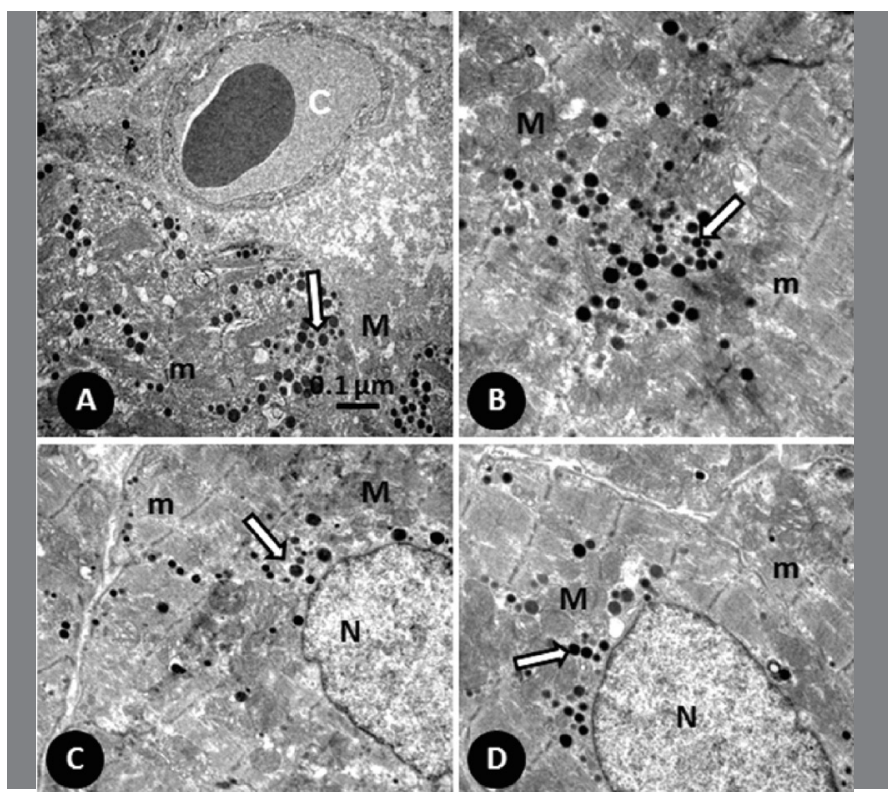

Figure 3. Electron photomicrographs of the right atrium cardiomyocytes of the 4 groups studied, showing the granules of natriuretic peptides [NPs] (arrows) dispersed in the cytoplasm, between myofibrils $(\mathrm{m})$ and mitochondria $(\mathrm{M})$ and close to the nuclei (N) of the cardiomyocyte. A-Control Group; B-Group Aerobics; C-Group Resistance; D-Group Combined. A can be seen in a capillary (C) containing a red blood cell.
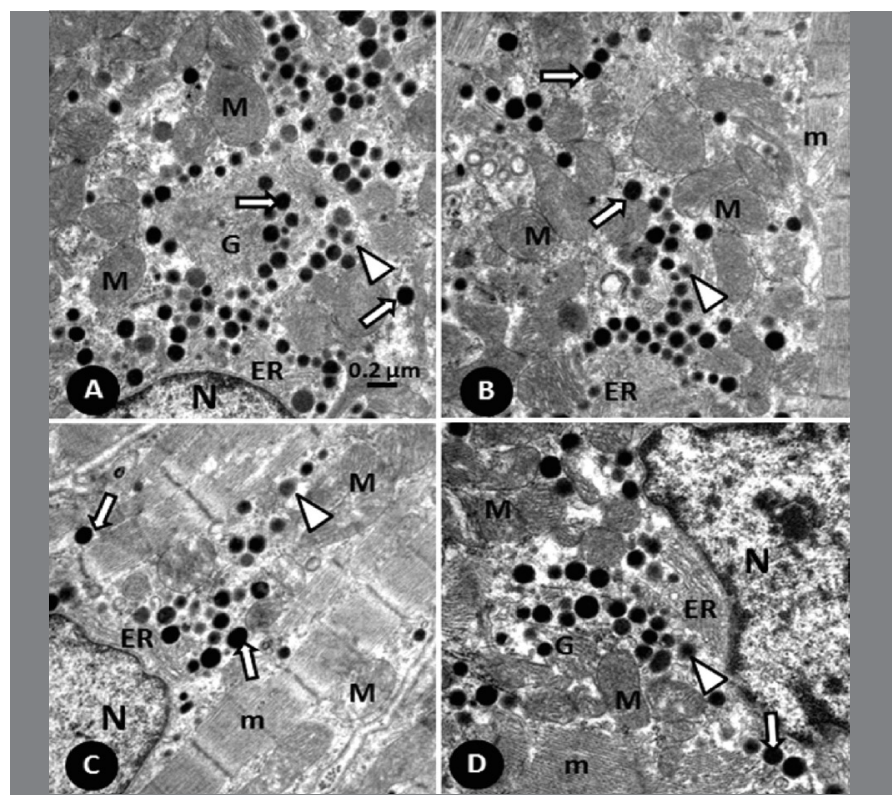

Figure 4. Electron photomicrographs of the right atrium cardiomyocytes of the 4 groups studied, showing the granules of natriuretic peptides [NPs] (arrows) in the cytoplasm of the cardiomyocyte. A-Control Group; B-Group Aerobics; C-Group Resistance; D-Group Combined. m-myofibrils; M-mitochondria. N-nucleus of the cardiomyocyte. 
There was no significant difference in the number of pores/10 $\mu \mathrm{m}$ between the groups studied ( $p>0.05$ ).

Figure 7 shows the frequency distribution of the ANP and BNP granules for their diameter in the 4 groups studied.

\section{Left Atrium}

The results showed that the numerical number and diameter of ANP granules were statistically different in all groups compared to GC $(p<0.05)$. (Figure 8)

There was a significant decrease in the density of ANP granules in the GA, GR and GAR group when compared to the GC group $(p<0.05)$.

The diameter of the ANP granules of the left atrium decreased by $10 \%$ in GA, $13 \%$ in GR and $15 \%$ in GAR compared to GC.

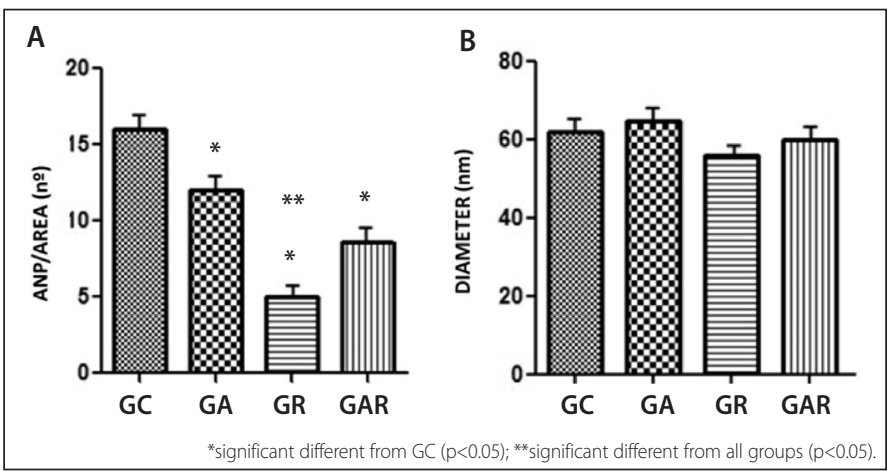

Figure 5. Graphs representative of the number per area (A) and diameter of the ANP (B) granules in the right atrium, in the GC, GA, GR, and GAR groups.

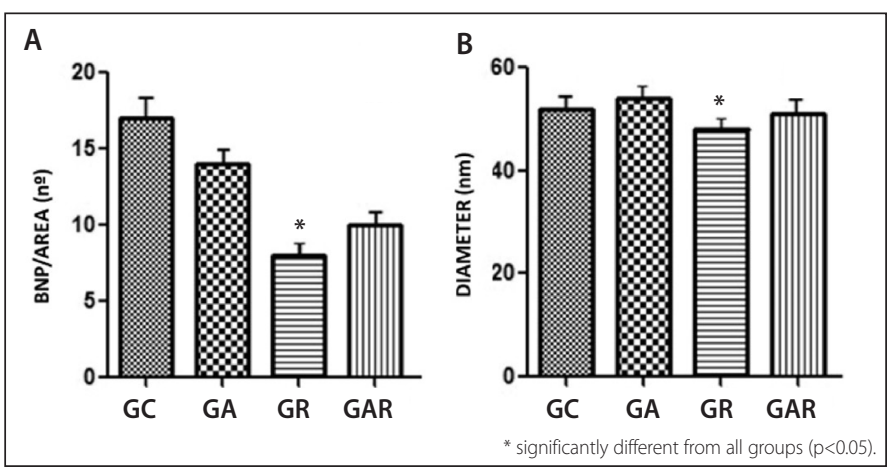

Figure 6. Graphs representative of the number per area (A) and diameter (B) of BNP granules in the right atrium, in the GC, GA, GR, and GAR groups.

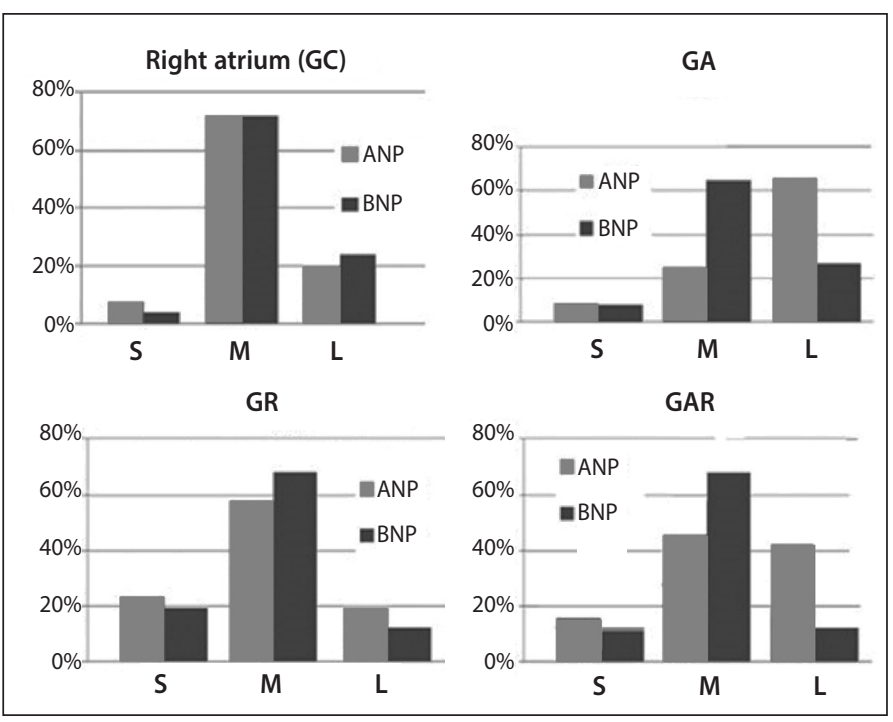

Figure 7. Histograms of the frequency distribution of the granules of ANP and BNP in the right atrium as to their diameter [small $(S)$ medium $(M)$ and large $(L)]$ in the Groups studied.
The results show that the number of BNP granules/area in the left atrium was fewer in all groups compared to CG $(p<0.05)$. However, no statistical difference was found for BNP granules diameter between exercise groups. (Figure 9)

In relation to the density of BNP granules, we observed a decrease of $34 \%$ of GA in relation to GC, a decrease of $43 \%$ of GR in relation to GC and decrease in $48 \%$ of $R G$ in relation to $G C$.

There was no significant difference in the number of pores/10 $\mu \mathrm{m}$ of the nuclear membrane between the groups studied.

Figure 10 represents the frequency distribution of the left atrium ANP and BNP granules, divided into small, medium and large, of the 4 groups studied.

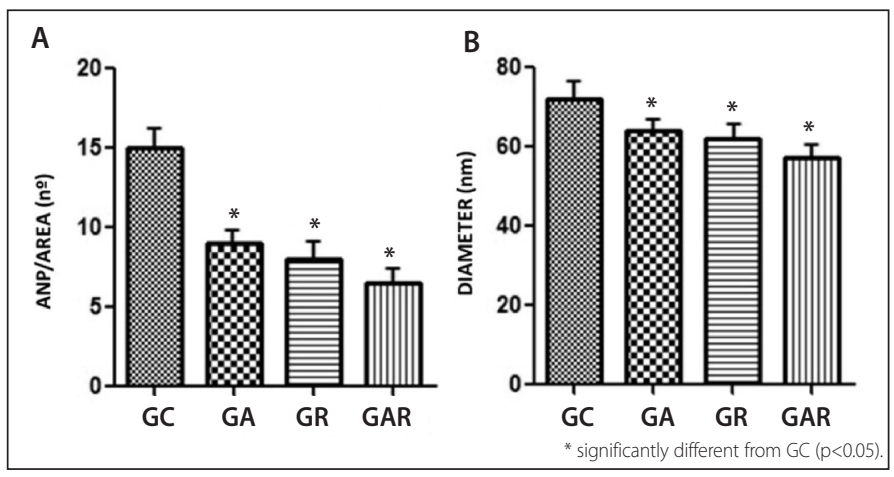

Figure 8. Graphs representative of the number per area and diameter of ANP granules in the left atrium, in the GC, GA, GR, and GAR groups.
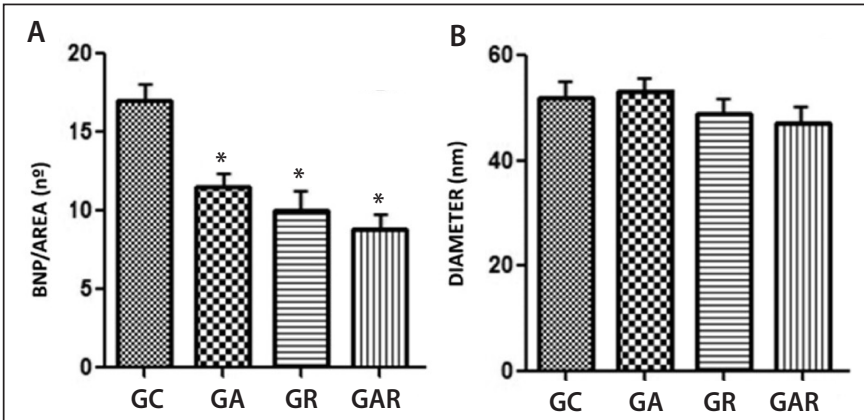

Figure 9. Graph representing the number by area and diameter of BNP granules in the left atrium, in the GC, GA, GR, and GAR groups.

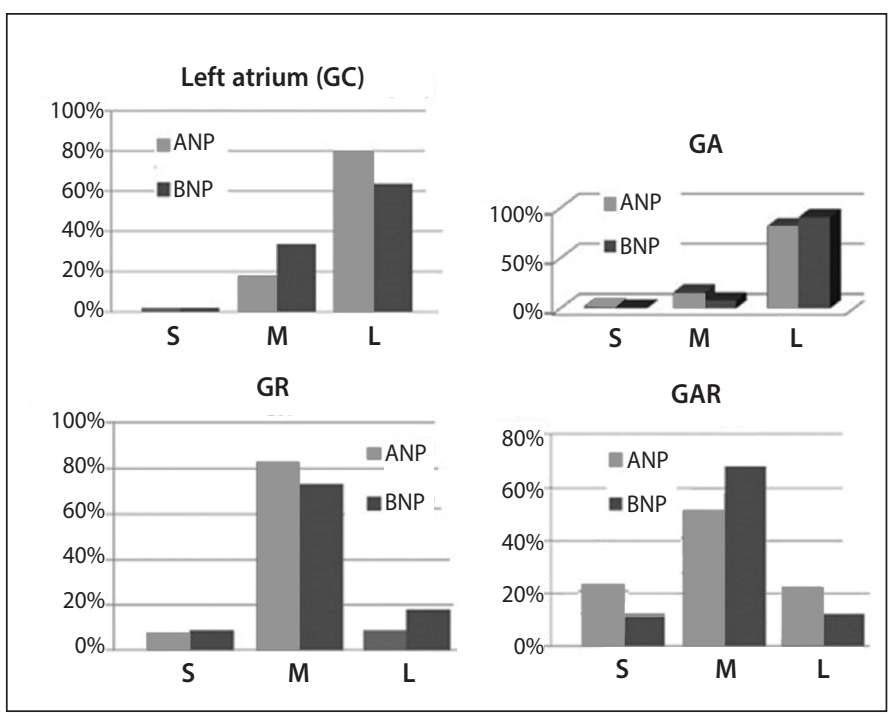

Figure 10. Histogram of the frequency distribution of ANP and BNP granules for their diameter [small (S) medium (M) and large (L)] in the left atrium of the GC, GA, GR, and GAR. 
Comparing data on the number of ANP granules between both atria, it is observed that the number of ANP granules per area in the GC was $16.83 \pm 1.5$ in the right atrium and $14.8 \pm 1.2$ in the left atrium. In $G A$ the right atrium was $12 \pm 1.2$ and the left atrium was $9.43 \pm$ 1.0. In $G R$, it was $5 \pm 0.5$ in the right atrium and $8.5 \pm 0.9$ in the left atrium. In the GAR, it was $8.3 \pm 1.3$ in the right atrium and $7.4 \pm 0.8$ in the left atrium.

Regarding the number of BNP granules per area, it was verified that in the CG, it was $17.41 \pm 1.2$ in the right atrium and $18.32 \pm 1.4$ in the left atrium. In GA, it was $13.95 \pm 1.4$ in the right atrium and $18.32 \pm 1.4$ in the left atrium. In the $G R$, it was $8.05 \pm 0.85$ in the right atrium and $10.55 \pm$ 1.2 in the left atrium. In the GAR, it was $10 \pm 1.8 \mathrm{in}$ the right atrium and $8.8 \pm 0.9$ in the left atrium.

It is verified after analysis of the ANP diameter data in the two atria, which in the right atrium GC was $61.9 \pm 1.4 \mathrm{~nm}$ and in the left atrium $72.2 \pm 0.75 \mathrm{~nm}$. In GA, it was $64.7 \pm 0.8 \mathrm{~nm}$ in the right atrium and 64.5 $\pm 0.9 \mathrm{~nm}$ in the left atrium. In the GR, it was $55.8 \pm 1.5 \mathrm{~nm}$ in the right atrium and $62.6 \pm 1.4 \mathrm{~nm}$ in the left atrium. In the GAR, it was $60.3 \pm 1.6$ $\mathrm{nm}$ in the right atrium and $60.4 \pm 0.80 \mathrm{~nm}$ in the left atrium.

Regarding the diameter of the BNP granules, it is observed that in the right atrium GC it was $52.04 \pm 0.64 \mathrm{~nm}$ and in the left atrium 52.2 $\pm 0.54 \mathrm{~nm}$. In GA, it was $54.68 \pm 0.75 \mathrm{~nm}$ in the right atrium and $53.75 \pm$ $0.75 \mathrm{~nm}$ in the left atrium. In GR, it was $48.49 \pm 0.41 \mathrm{~nm}$ in the right atrium and $49.99 \pm 0.54 \mathrm{~nm}$ in the left atrium. In the GAR, it was $53.9 \pm 0.6 \mathrm{~nm}$ in the right atrium and $47.8 \pm 0.53 \mathrm{~nm}$ in the left atrium.

\section{DISCUSSION}

Analysis of the ANP and BNP granules was performed in electronic photomicrographs in an appropriate computerized image analysis system. The production of ANP and BNP depends on the integrity and structure of the nuclear membrane of the cardiomyocyte since the nuclear membrane of eukaryotic cells is fundamental in the mechanism of the passage of substances from the nucleus to the cytoplasm and vice-versa. ${ }^{21}$ The involvement of this membrane in the regulation of nuclear functions, including transcription and replication, for the production of proteins in the cytoplasm, is fundamental for the production of ANP and BNP in different stress situations to which cells are submitted. ${ }^{22}$ Interesting, neither groups presented any alterations in the number of nuclear pores. This result can be explained by the type of analysis performed in this study, whose acute outcome prevents any type of temporal analysis. Knowing that morphological changes depend on more time to occur, we suggest that new studies re-evaluate this structure using more chronic physical training.

Thus, there are four important findings in the present study. First, rats submitted to aerobic, resistance and combined exercise showed a significant decrease in the ANP granules density in both atrium, when compared to the GC. Second, the size of the ANP granules from all exercise types significantly decreased in relation to the GC, however only in the left atrium. Third, BNP density decreased significantly in both atrium among all groups compared to GC. Fourth, the BNP granule size decrease in the right atrium was significantly verified only in the rats that underwent resistance exercise.

Here, we showed that animals which trained with aerobic, resistance and combined exercises showed a significant decrease in ANP and BNP levels compared to sedentary animals. This decrease is due to the need for a greater quantity of these peptides in the circulation to control cardiovascular response during exercise. These findings corroborate those of Ohba et al ${ }^{9}$ and Barletta et al, ${ }^{19}$ that observed a significant increase of these peptides in the plasma of marathoners and cyclists during specific training of both modalities.

In addiction, we found similar findings for both types of granules, ANP and $B N P$, in relation to acute exercise. Among these, we can mention: first, the amount of ANP and BNP produced and released were similar in both atria. Second, the diameter of ANP and BNP significantly decreased in the left atrium. Third, the exercise intervention that promoted greater significant decrease of ANP and BNP and a significant decrease of ANP and BNP diameter was resistance exercise.

The decrease in the amount of BNP found in the group that was submitted to the resistance exercise was greater than that seen in the ANP. As known, resistance exercise promotes a more significant acute increase in blood pressure levels, since the muscular contraction in this type of motor task is more vigorous, causing a greater peripheral resistance and, consequently, a higher acute elevation of pressure levels. As BNP is used in emergency situations, such as in response to ventricular overload, it will act faster than the ANP in the renal tubules, possibly to act decreasing BP as evidenced in several studies. ${ }^{23,24}$

In the trained animals, the number of large BNP granules was lower than in the GC, which means that these granules are those that were used to maintain BP at satisfatory levels. Thus, it is understood that large BNP granules would be ready to be released into the circulation and, therefore, their amount in the cardiomyocytes becomes smaller after a training session.

Regarding ANP granules, the present study demonstrated, in contrast to BNP granules, in both atria, a larger number of large ANP granules in animals that underwent aerobic exercise and combined training compared to CG animals. This means that there was a greater release of ANP from the medium and small granules. Animals that underwent resistance training did not present this alteration. This finding corroborates the study of De Souza et $\mathrm{al}^{25}$ since the large granules are likely to be used with the prolongation of the physical training, that is, after the acute phase of the training.

\section{CONCLUSIONS}

The analysis of the results obtained allows to elaborate the following conclusions: First, the right atrium released more ANP and BNP during all types of exercises; Second, the resistance exercise freed the most ANP and BNP in both atria; Third, in the right atrium, aerobic and combined workouts released more small and medium ANP granules while resistance exercise released larger BNP granules; and Forth, in the left atrium, aerobic exercise released more medium ANP beads while resistance and combined exercise released larger ANP and BNP granules.

\section{ACKNOWLEDGMENTS}

We would like to thank all the technicians who helped us prepare the material for analysis. This article followed all the procedures required through the authorization of the ethics committee in animal experimentation.

All authors declare no potential conflict of interest related to this article

AUTHORS' CONTRIBUTIONS: Each author made significant individual contributions to this manuscript. EVP (0000-0001-7775-1222)*: writing, revision, training of the animals, preparation of the material for analysis and preparation of the final text; WKN (0000-0002-6881-0208)*: translation of the manuscript, data analysis and writing, statistical analysis and final preparation of the manuscript; ASS (0000-0002-0252-1366)*: writing, revision of the data and final preparation of the manuscript; EFG (0000-0002-9770-8819)*: revision and joint guidance of the entire project, final analysis of the data and preparation of the manuscript, and RRS (0000-0002-3251-276X)*: writing, guidance of the entire project and final preparation of the manuscript, revision and intellectual concept *ORCID (Open Researcher and Contributor ID). 


\section{REFERENCES}

1. Gama EF, Souza RR, Pianca EV. Atrial natriuretic peptide (ANP)-granules: ultrastructure, morphometry and function. African Journal of Biotechology. 2006;5(25):2534-9.

2. Moroni F, Ammirati E, Rocca MA, Filippi M, Magnoni M, Camici PG. Cardiovascular disease and brain health: Focus on white matter hyperintensities. Int J Cardiol Heart Vasc. 2018;14(19):63-69.

3. Vasan RS, Larson MG, Leip EP. Impact of high-normal blood pressure in the risk of cardiovascular disease. N Engl J Med. 2001;345(18):1291-7.

4. Campagnole-Santos MJ, Haibara AS. Reflexos cardiovasculares e hipertensäo arterial. Rev Bras Hipertens. 2001;8:30-40.

5. Libianto R, Batu D, Maclsaac RJ, Cooper ME, Ekinci El. Pathophysiological links between diabetes and blood pressure. Can J Cardiol. 2018;34(5):585-94.

6. Razvi S, Jabbar A, Pingitore A, Danzi S, Biondi B, Klein I, et al. Thyroid hormones and cardiovascular function and diseases. J Am Coll Cardiol. 2018;71(16):1781-96.

7. Shaw I, Rider S, Mullins J, Hughes J, Péault B. (2018) Pericytes in the renal vasculature: roles in health and disease. Nat Rev Nephrol. 2018;14(8):521-34.

8. Nakao K, Itoh H, Suga S, Ogawa Y, Imura H. The natriuretic peptide family. Curr Opin Nephrol Hypertens. 1993;2(1):45-50.

9. Ohba H, Takada H, Musha H, Nagashima J, Mori N, Awaya T, et al. Effects of prolonged strenuous exercise on plasmalevels of atrial natriuretic peptide and brain natriuretic peptide in healthy men. Am Heart J. 2001;141:751-8

10. Fenzl M, Schnizer W, Aebli N, Schlegel C, Villiger B, Disch A, et al. Release of ANP and fat oxidation in overweight persons during aerobic exercise in water. Int J Sports Med. 2013;34(9):795-9.

11. Mifune H, Suzuki S, Honda J, Kobayashi Y, Noda Y, Hayashi Y, et al. Atrial natriuretic peptide (ANP): a study of ANP and its mRNA in cardiocytes, and of plasma ANP levels in non-obese diabetic mice. Cell Tissue Res. 1992;267(2):267-72

12. Saito Y, Nakao K, Sugawara A, Nishimura K, Sakamoto M, Morii N, et al. Atrial natriuretic polypeptide during exercise in healthy man. Acta Endocrinol (Copenh). 1987;116(1):59-65

13. de Bold AJ. Atrial natriuretic factor: a hormone produced by the heart. Science. 1985;230(4727):767-70.
14. Dicstein K. Natriuretic peptides in the detection of heart failure. Lancet. 1998;351(9095):4.

15. Brum PC, Forjaz CL, Tinucci T, Negrão CE. Adaptações agudas e crônicas do exercício físico no sistema cardiovascular. Rev Paul Educ Física. 2004;18(N. esp):21-31.

16. Squires RW, Shultz AM, Herrmann J. Exercise training and cardiovascular health in cancer patients. Curr Oncol Rep. 2018;20(3):27.

17. Wallace RG, Twomey LC, Custaud MA, Turner JD, Moyna N, Cummins PM, et al. The role of epigenetics in cardiovascular health and ageing: a focus on physical activity and nutrition. Mech Ageing Dev. 2018;174:76-85.

18. Wewege MA, Thom JM, Rye KA, Parmenter BJ. Aerobic, resistance or combined training: a systematic review and meta-analysis of exercise to reduce cardiovascular risk in adults with metabolic syndrome. Atherosclerosis. 2018;274:162-71.

19. Barletta G, Stefani L, Del Bene R, Fronzaroli C, Vecchiarino S, Lazzeri C, et al. Effects of exercise on natriuretic peptides and cardiac function in man. Int J Cardiol.1998;65(3):217-25.

20. Hornberger TA Jr, Farrar RP. Physiological hypertrophy of the FHL muscle following 8 weeks of progressive resistance exercise in the rat. Can J Appl Physiol. 2004;29(1):16-31.

21. Souza RR, Oliveira VC, Pithon-Curi TC, Maldonado DC. Effects of ovariectomy on the secretory apparatus in the right atrial cardiomyocytes of middle-aged mice. Clinics (São Paulo). 2014;69(8):554-8.

22. Julienne H, Zoufir A, Audit B, Arneodo A. Human Genome Replication Proceeds through the Four Chromatin States. PLoS Computational Biology. 2013;9(10):e1003233.

23. Cardoso CG Jr, Gomides RS, Queiroz AC, Pinto LG, da Silveira Lobo F, Tinucci T, et al. Acute and chronic effects of aerobic and resistance exercise on ambulatory blood pressure. Clinics (São Paulo). 2010;65(3):317-25.

24. Bertani RF, Campos GO, Perseguin DM, Bonardi JM, Ferriolli E, Moriguti JC, et al. Resistance exercise training is more effective than interval aerobic training in reducing blood pressure during sleep in hypertensive elderly patients. J Strength Cond Res. 2018;32(7):2085-90.

25. Souza RR, Caldeira CA, Carbone PO, Pianca EV. Influence of glutamine on the effect of resistance exercise on cardiac ANP in rats. Rev Bras Cienc Esporte. 2015;37(1):74-9. 